University of Massachusetts Amherst

From the SelectedWorks of James Crotty

July, 2003

The Neoliberal Paradox: The Impact of Destructive Product Market Competition and Impatient Finance on Nonfinancial Corporations in the Neoliberal Era

James Crotty, University of Massachusetts - Amherst 


\title{
The Neoliberal Paradox: \\ The Impact of Destructive Product Market Competition and Impatient Finance on Nonfinancial Corporations in the Neoliberal Era
}

\author{
James Crotty* \\ July 2003
}

Research Brief 2003-5

The emergence in the late 1970s of the global neoliberal economic order has had a number of negative effects on general economic performance. This Research Brief focuses on its effect on large US nonfinancial corporations (NFCs). In this Brief, I accept the thesis associated with Joseph Schumpeter and Alfred Chandler that large NFCs operating in oligopolistic markets were the main source of most of the capital investment, technological change and productivity growth in the Golden Age. I argue that NFC performance was adversely affected by two major changes created by neoliberal globalization: (1) a slowdown in the rate of global growth and an increasing intensity of competition in key product markets that caused a downturn in NFC profit rates; and (2) a shift from "patient" finance to impatient financial markets that raised real interest rates, forced NFCs to pay an increasing share of their cash flow to financial agents, drastically changed managerial incentives, and helped shorten NFC planning horizons.

NFCs were eventually placed in a neoliberal paradox: intense product market competition made it impossible for most NFCs to achieve high earnings most of the time, but financial markets demanded that NFCs generate ever-increasing earnings and ever-increasing payout ratios to financial agents or face falling stock prices and the threat of hostile takeover.

In several recent papers I used insights from Schumpeter, Keynes and Marx to explain why key nonfinancial product markets in the neoliberal era have been characterized by low profit rates, high leverage and chronic excess capacity (Crotty 2000a, Crotty 2000b, Crotty 2002a, and

\footnotetext{
* James Crotty is Professor of Economics at the University of Massachusetts-Amherst. The author would like to thank the Political Economy Research Institute for generous research support, to Alper Duman and Ozgur Orhangazi for excellent research assistance, to Robert Pollin for helpful comments, and to Rob Parenteau for help with data and financial accounting puzzles.
} 
Crotty 2003). This Research Brief deals with the impact of changes in the relation between NFCs and financial markets over this period. ${ }^{\dagger}$

\section{The Rise of the Financial or Portfolio Conception of the NFC in Financial Markets}

I stress two aspects of the changing relation between financial markets and large NFCs. The first is a shift in the beliefs of financial agents, from an implicit acceptance of the Chandlerian view of the large NFC as an integrated combination of illiquid real assets - that is, physical and organizational assets that cannot be sold for cash quickly and without a major loss in value assembled to pursue long-term growth and innovation, to a "financial" conception in which the NFC is seen as a 'portfolio' of liquid subunits that home-office management must continually restructure to maximize the stock price at every point in time. The second is a fundamental change in management's reward structure, from one that linked pay to the long-term success of the firm, to one that links it to short-term stock price movements.

The 1960s conglomerate merger movement initiated a change in the perception of the proper role of top management, from one in which managers were expected to be experts in the main business of the firm, to an evolving view of top executives as generalists who knew how to buy and sell subsidiaries as business conditions changed. This shift remained incomplete, however, until the hostile takeover movement of the 1980s, which forced NFC insiders to either divest units whose stock price fell below the level demanded by Wall Street or yield control of the firm to corporate raiders. Raiders relied primarily on debt to finance takeovers, while managers of targeted firms often defended their turf by loading the firm with debt-financed stock buybacks and special cash dividends to deter potential raiders. These developments pushed NFC debt burdens to historic highs. They also forced a change in managerial goals, from concern with the long-term success of the firm to a short-term obsession with keeping the stock price high enough to deter a hostile takeover.

\section{The "Shareholder Value" Movement: A New Alliance Between NFC Managers and Financial Investors}

Throughout the $1950 \mathrm{~s}$, households owned about $90 \%$ of corporate stock and tended to hold their stocks for long periods. At the end of the 1970s, household stock ownership dropped to $59 \%$. In 2000 , households held $42 \%$ of public shares, while US institutions owned $46 \%$ and were responsible for about three-quarters of all stock trades.

Intense competition among institutional investors to get and hold contracts to manage large portfolios led to constant asset 'churning' in pursuit of short-term capital gains. Turnover on the New York Stock Exchange was about 20\% from 1960 through the late 1970s. It increased to over $70 \%$ in $1983-87$, the most hectic phase of the hostile takeover movement, then was pushed above $100 \%$ as the shareholder value movement of the 1990 s moved into full swing. On average, stocks are now held for just one year. Since rational stockholders now have no reason to

\footnotetext{
$\dagger$ A complete exposition of these issues that includes a discussion of the "financialization" of NFCs can be found in the PERI Working Paper: James Crotty, "Slow Growth, Destructive Competition, and Low Road Labor Relations: A Keynes-Marx-Schumpeter Analysis of Neoliberal Globalization," 2000b, http://www.umass.edu/peri/pdfs/WP6.pdf.
} 
concern themselves with the performance of the companies they 'own' beyond a one-year horizon, stock price movements primarily reflect short-term speculative pressures, not long-term "fundamentals."

But pressure to keep stock prices rising also became internalized within NFC top management. Institutional investors tried to force management to meet their need for ever-higher stock prices through the spreading use of stock options. By the late 1990s, the dominant component of the pay of the management teams running America's largest NFCs was stock-price driven. The average proportion of the earnings of the top 100 CEOs that came in the form of exercised stock options rose from $22 \%$ in 1979 to $50 \%$ in the late $1980 \mathrm{~s}$. In the financial boom years of 1995 through 1999, this average rose to 63\%. Meanwhile, top CEO pay in all forms rose from \$1.26 million in 1970, to \$37.5 million in 1999 (Piketty and Saez 2001, Table B4). Gargantuan payments thus accrued to managers who could get their company's stock price above a trigger level - even for one minute.

In the late 1990s bubble, the investing classes came to believe that annual gains on stock portfolios in excess of $20 \%$ would go on forever. Institutional investors demanded that NFCs produce rapid earnings growth so they could satisfy their clients, while top NFC managers needed to generate rapidly rising stock prices or their stock options would be worthless. Thus, by the late 1990s, the rational pursuit of self interest by top managers led them to do whatever it took to keep stock prices rising even in the shortest of runs, an objective that required ever-rising reported earnings.

\section{The Logic of Financial Market Evolution: The US Stock Market Collapse, and the Crisis of Confidence in the US Financial System}

From its peak in July 2000 to early October 2002, the S\&P 500 stock price index fell by more than $45 \%$, while the Nasdaq index fell by about $75 \%$. This stock market meltdown was accompanied by the worst US financial scandal since the $1920 \mathrm{~s}$.

To understand how the fraud of this magnitude could have taken place in the richest country in the world, one that was believed to possess the deepest, most efficient, most transparent, and most "efficiently" regulated financial markets, one must understand the neoliberal paradox. Destructive competition in product markets in the past quarter century severely constrained the ability of NFCs to earn high profits and cash flow, yet financial markets and managerial incentives demanded ever-rising earnings to support ever-rising stock prices.

An unsustainable combination of forces led to a substantial rise in the NFC profit rate in the mid 1990s, but it peaked in 1996 and fell rapidly in 1998 through 2000. Yet financial market pressures and new NFC management incentives required that reported earnings rise virtually every quarter to prevent $\mathrm{P} / \mathrm{E}$ ratios and stock prices from falling. Many of the largest NFCs reporting the fastest growing earnings, such as Enron and WorldCom, were "serial acquirers." By adding more and more businesses, these NFCs in effect bought the new earnings they could not gain through expansion in traditional product markets because of destructive competition. In the end, when even this strategy was not enough to keep earnings on the rise, management simply cooked the books. 
Few people were aware of the extent to which these reporting distortions had grown by the decade's end. Yet evidence of massive fraud was freely available. Government data showed that profits as a percent of value added in NFCs peaked in mid 1997 and fell by over $20 \%$ in the next two years (Council of Economic Advisers 2002a, p. 339). Nevertheless, profits reported by S\&P 500 corporations rose by $42 \%$ from 1997 to 2000 . Financial asset prices in the late $1990 \mathrm{~s}$ were driven by fraudulent information interpreted irrationally in a kind of mirror image of a neoclassical "efficient" financial markets model.

Severe conflicts of interest deeply embedded in the financial system allowed widespread fraud to take place. NFC managers with huge stock options were aided in their efforts to deceive investors by giant accounting firms that signed off on misleading financial statements because consulting contracts with these firms earned them more than auditing. Bank stock analysts issued only "buy" recommendations even when they knew better because their firms needed the investment banking and loan business of the same NFCs they were evaluating. Congress defeated all proposals to force firms to provide accurate income and balance sheet information because the financial and accounting industries are among the largest campaign contributors to Washington politicians in an era when elections are obscenely expensive.

\section{Financial Agents Have Extracted an Increasing Share of NFC Cash Flow: Empirical Evidence from the Fed's Flow of Funds}

These changes in product and financial markets and in the incentives guiding management led to a qualitative jump in the percent of NFC cash flow taken by financial agents. Figure 1 shows NFC net interest payments as a percent of cash flow. It shows that this ratio remained at about 15\% from the end of the 1960s until the early 1980s, at which point super-high real interest rates brought on by Paul Volcker's temporary conversion to monetarism followed by the debt-generating hostile takeover movement caused it to rise by decade's end to a post-war high of $30 \%$. It then fell back toward 1970s levels in the mid to late 1990s as real interest rates declined, interest received increased, and cash flow rose.

Figure 1: NFC Net Interest Payments as a Percent of Cash Flow

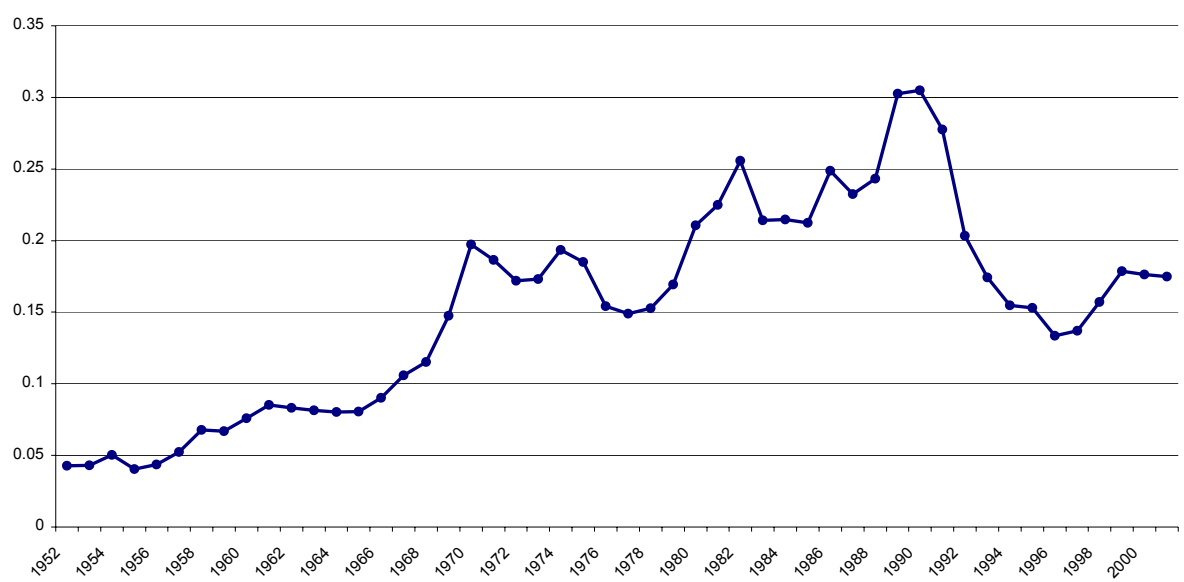


Figure 2 shows that the proportion of NFC cash flow extracted by financial markets in the form of dividends actually declined after the 1950s and 1960s. However, the rise of the shareholder value movement caused the dividend payout burden to double from mid 1980s to the late 1990s, severely draining NFC funds.

Figure 2: NFC Dividends as a Percent of Cash Flow

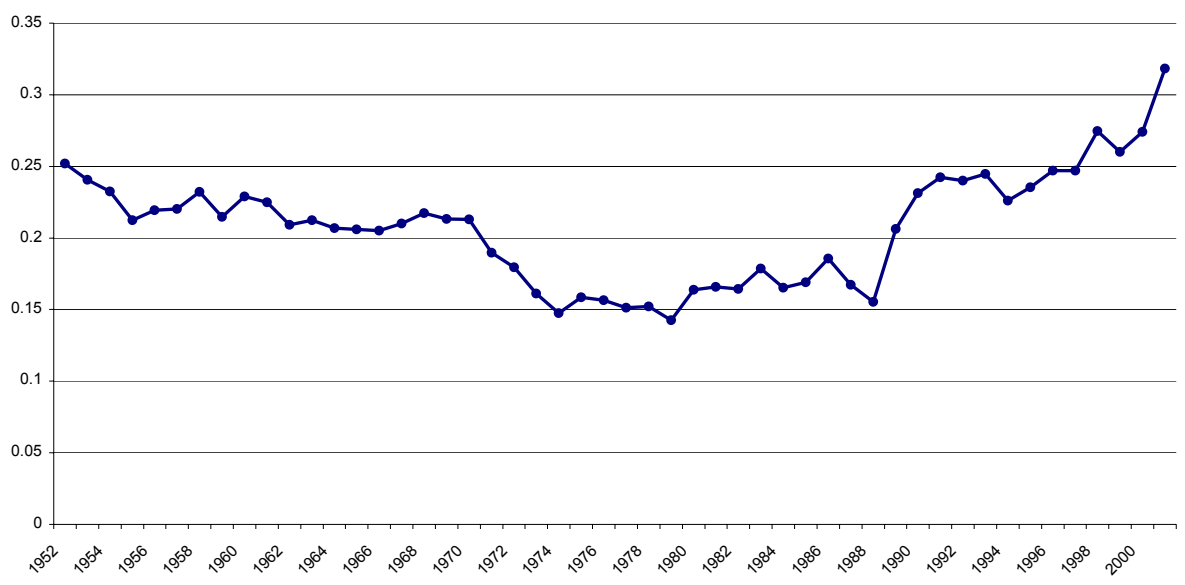

Figure 3 shows net NFC stock purchases as a percent of cash flow. Until the 1980s, NFCs were net sellers of equity, though they never raised large sums in the equity market. In the hostile takeover movement of the 1980s, NFC management bought its own stock to keep the raiders from the door, while a wave of mergers removed stock from the hands of the public. From 1984 through 1989, stock purchases ate up over 20\% of cash flow. Net purchases dropped off in the early 1990s, but rose again after 1993 as the shareholder value movement gained strength. Stock buybacks had to be large enough to maintain upward pressure on stock prices in the face of large sales from exercised options. From 1995 through 2001, NFCs purchased $\$ 870$ billion of their own stock, helping prolong the bubble.

Figure 3: NFC Stock Buybacks as a Percent of Cash Flow

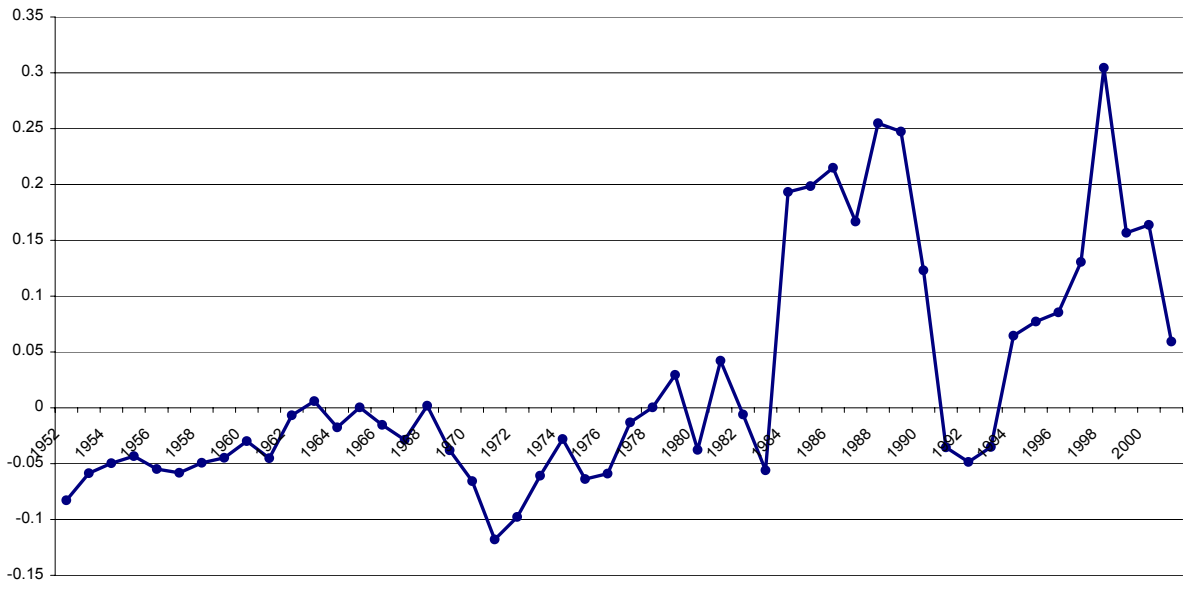


Figure 4 shows total NFC payments to financial markets as a percent of cash flow. It thus brings together product and financial market pressures impinging on NFCs. Destructive competition constrained NFC cash flow, while financial markets forced NFCs to disgorge a growing share of their shrinking cash flow to financial agents. Financial market payments rose from relatively low levels in the 1950s to about 30\% of cash flow from the mid 1960s through the late 1970s. But from 1984 through 2000, with the exception of three recession years in the early 1990s, NFCs paid out well over half their cash flow to financial agents. From 1984 through 1990 and again from 1997 through 2001, this ratio never fell below 50\%. It peaked at 76\% in 1989 and again at $74 \%$ in 1998.

Figure 4: Total Payments to Financial Markets by NFCs as a Percent of Cash Flow

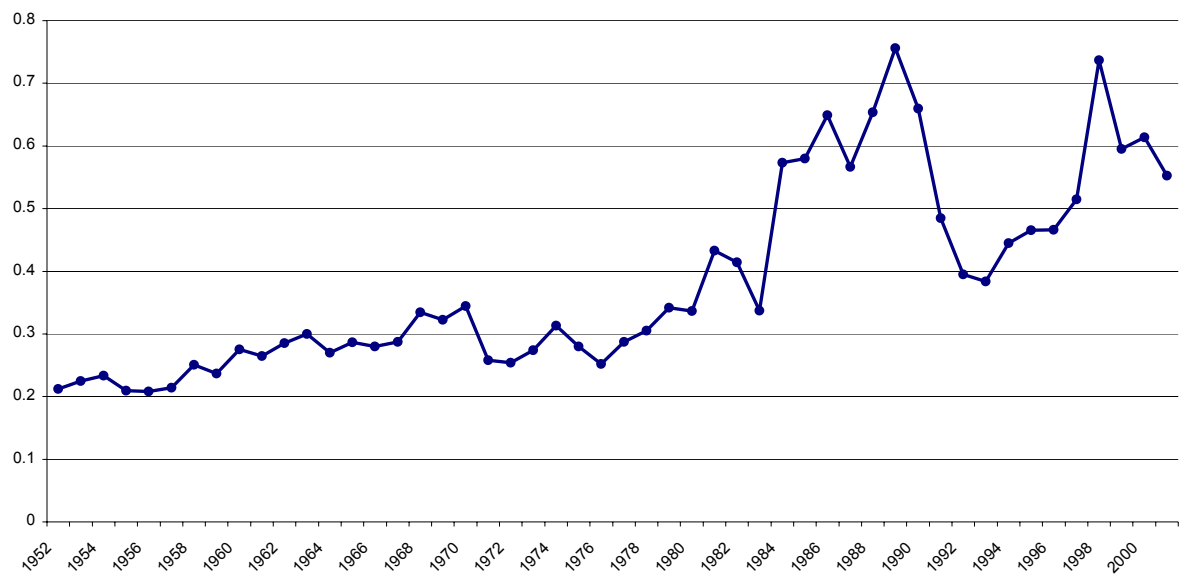

Thus, the lion's share of NFC finance is now provided on the shortest of terms. NFCs must disgorge over half of the cash flow they need to sustain investment and innovation over the long term, then compete with all other agents, foreign and domestic, to get it back. This is impatient capital in its most extreme form. It forces NFCs to either cut investment and innovation or face rising indebtedness. And it sustains cost-cutting pressure and 'low-road' labor relations, which retard wage and employment growth and thus constrain the growth of aggregate demand.

\section{Conclusion}

Neoliberal globalization is destroying conditions in both product and financial markets that are necessary for the successful long-term performance of large nonfinancial firms and the economies that depend on them. It will not be possible for NFCs to lead either advanced or developing nations to long-term prosperity unless the neoliberal project is abandoned. 


\section{References}

Chandler, Alfred. Scale and Scope: The Dynamics of Industrial Capitalism (Cambridge: Harvard University Press, 1990).

Council of Economic Advisers. Economic Report of the President (Washington: US Government Printing Office, 2002a).

Crotty, James. "Structural Contradictions of the Global Neoliberal Regime," Review of Radical Political Economics, 32 (3), Sept. 2000a, pp. 361-68.

Crotty, James. "Slow Growth, Destructive Competition, and Low Road Labor Relations: A Keynes-MarxSchumpeter Analysis of Neoliberal Globalization," 2000b, http://www.umass.edu/peri/pdfs/WP6.pdf.

Crotty, James, "Why Is There Chronic Excess Capacity," Challenge, November/December 2002a, 45 (6), pp. 21-44.

Crotty, James, "The Effects of Increased Product Market Competition and Changes in Financial Markets on the Performance of Nonfinancial Corporations in the Neoliberal Era" 2002b, http://www.umass.edu/peri/pdfs/WP44.pdf.

Crotty, James, "Core Industries, Coercive Competition and the Structural Contradictions of Global Neoliberalism." In N. Phelps and P. Raines, eds., The New Competition for Inward Investment: Companies, Institutions and Territorial Development. Northampton Mass.: Edward Elgar, forthcoming 2003.

Lazonick, William and Mary O'Sullivan, "Organization, Finance and International Competition," Industrial and Corporate Change, 5 (1), 1996, 1-49.

Piketty, Thomas and Emmanuel Saez, "Income Inequality in the United States: 1913-1998," Working Paper 8467, National Bureau of Economic Research, 2001.

Schumpeter, Joseph. Capitalism, Socialism and Democracy (London: George Allen \& Unwin, 1976 [1943]). 